\title{
Effect of Carob and ginger herbs on induced nephrotoxicity in rats
}

\author{
Ereny Wilson, Haiam Elkatry
}

\author{
Home Economics Department, Faculty of Specific Education, Ain Shams University, Cairo, \\ Egypt.
}

\begin{abstract}
Carob (Ceratonia siliqua) and ginger (Zingiber Officinale) are typical mediterranean plant, mainly used in food and Egyptian traditional folk medicine. The aim of this study is to investigate the protective effects of carob and ginger on induced nephrotoxicity in rats. The nephroprotective effects of carob and ginger $(0.5,1.0$ and $5 \%)$ were investigated using cisplatin $(2.5 \mathrm{mg} / \mathrm{kg}$ body weight) to induce renal dysfunction in rats. The results showed that cisplatin administration elevated levels of plasma cholesterol, triglyceride (TG), very low density lipoprotein (VLDL), low density lipoprotein (LDL)-cholesterol and caused abnormal renal functions in all studied rats. Serum urea and creatinine concentrations were significantly higher $(P<0.5)$ in rats treated with cisplatin (positive control group $B$ ) compared to the normal group (negative control group A). Diet supplemented with carob or ginger at (5\%) showed a significant reduction in the serum total cholesterol and total triglycerides levels by $34.1,40.0 \%$, and $33.6,45.4 \%$ respectively. Carob and ginger ameliorated cisplatin-induced nephrotoxicity as indicated by significant decrease in serum urea and creatinine concentrations compared to the positive control. The same trend was observed with uric acid and nitric oxide. Thus, carob and ginger may be used to delay the toxic effect of the chemotherapeutic treatment with cisplatin.
\end{abstract}

Key Words: Carob, ginger, cisplatin, nephrotoxicity, rats

\section{Introduction}

The kidneys are routinely exposed to high concentrations of medications or their metabolites because their intrinsic function is to metabolize, concentrate, and excrete compounds. Therefore, it is not surprising that, as with prescribed medications, many dietary supplements have been associated with nephrotoxicity, either as a direct toxic effect, or secondary to liver dysfunction, rhabdomyolysis, or nephrolithiasis. It is clear that although many dietary supplements may not be harmful, some have been associated with renal dysfunction and others have the potential to do so (Thomson et al., 2002). Renal system is actively involved in drug elimination from body through renal filtration process, proximal tubule secretion and distal tubule reabsorption. It is well known that most of drugs, including: antibiotics, nonsteroid anti-inflammation, radiographic contrast media and some of cancer remedies, may cause renal failure. Although damage maybe reversible, it may cause chronic changes in kidney parenchyma. (Murcia et al., 2004)

Cisplatin is a widely used as antineoplastic agent for the treatment of metastatic tumors of the testis, metastatic ovarian tumors, lung cancer, advanced bladder cancer and many other solid tumors (Sweetman, 2002). The cytotoxic action of the drug is often through its ability to bind DNA to form cisplatin-DNA adducts (Goldstein and Mayor, 1983). Although higher doses of cisplatin are more efficacious for the suppression of cancer, high dose therapy manifests irreversible renal dysfunction and other toxicities (Halliwell and Cross, 1994; Simic and Jovanovic, 1986). Various data indicate that cisplatin induces oxidative stress (Ajith et al., 2002), lipid peroxidation (Bompart, 1989; Matsushima et al., 1998) and DNA damage (Lieberthal et al., 1996). Therefore administration of antioxidants has been shown to 


\section{Ereny Wilson and Haiam Elkatry}

ameliorate cisplatin-induced nephrotoxicity in various species of animals (Somani et al., 2000). The mechanism of protective effects of antioxidants against cisplatin nephrotoxicity is not fully known.

Ceratonia siliqua (C. siliqua), commonly known as Carob, belongs to the family of Leguminosae. The leaves and fruit of this plant are used to cure various diseases. Carob pods have traditionally been used as animal and human food and the seed is mainly used for gum extraction (Kivçak et al., 2002). From the experimental and clinical studies performed on C. siliqua, it seems that most of its pharmacological actions are due to its antioxidant activity which is mainly due to its ability to scavenge free radicals and/or inhibit lipid peroxidation (Kumazawa et al., 2002).

Carob pods contain lots of polyphenols, especially highly condensed tannins. A phenolic analysis revealed high contents of different forms of gallic acid (free gallic acid, gallotannins, and methyl gallate) and large amounts of quercetin and myricetin derivatives (Owen et al., 2003; Papagiannopoulos et al., 2004). Thus, carob fiber combines two positive nutritional ingredients, namely polyphenols and dietary fiber. Recent studies discovered that carob fiber has cholesterol lowering activities in persons suffering from hypercholesterolemia (Zunft et al., 2001; Zunft et al., 2003). There are other reported antioxidants properties in different in vitro test systems (Haber, 2002).

Zingiber Officinale commonly called ginger belongs to the family Zingiberaceae. The plant is a knotted, thick, beige underground stem (rhizome) that has been used in traditional medicine to aid digestion and treat stomach upset, diarrhea, nausea, and arthritis for centuries. In addition to these medicinal uses, ginger continues to be valued around the world as an important cooking spice and is believed to help the common cold, flulike symptoms, headaches, and even painful menstrual periods. Today, ginger root is widely used as a digestive aid for mild stomach upset and is commonly recommended by health care professionals to help prevent or treat nausea and vomiting associated with motion sickness, pregnancy, and cancer chemotherapy (Bone et al., 1990; Grontved et al., 1988; Sripramote and Lekhyananda, 2003).

The fresh ginger rhizome contains polyphenolic compounds such as gingerols (6-gingerol, 8-gingerol); zingerone, which is the major active component (Gruenwald et al., 2000); and gingerol [5-hydroxy-1-(4-hydroxy-3-methoxy phenyl) decan-3-one is one of the most abundant constituents in the gingerol series and also responsible for its characteristic pungent taste (Ney et al., 1988). Despite the favorable pharmacological properties of ginger, its protective effect against nephrotoxicity by cisplatin has not previously been explored and its role as diminished factor of fibrosis could be a marker of therapeutic benefit.

The aim of the present study is to evaluate the effects of carob (ceratonia siliqua), and ginger root (Zingiber Officinal R.) at different concentrations $(0.5,1$ and $5 \%$ as a starch replacer) on cisplatin-induced nephrotoxicity in rats.

\section{Materials and Methods}

\section{Samples of herb:}

Dried carob (Ceratonia siliqua), dried ginger root (Zingiber Officinal R.) were purchased from Agricultural Seed, Spices and Medicinal Plants Co., Bab El-khalk, Cairo, Egypt.

\section{Chemicals:}

Cis - diammine dichloride platinum and kits to biochemical analysis were purchased from Sigma- Aldrich Chemical Co. 


\section{Egypt. J. of Nutrition and Health Vol. 7 No. 1 (2012)}

\section{Experimental Animals:}

Fifty six male albino rats weighing $(190 \pm 10 \mathrm{~g})$ of Sprague Dawley Strain were obtained from Helwan experimental animals station. All rats were housed individually in well- aerated stainless steel experimental animals' cages and fed for one week a standard diet for adaptation, in air conditioned room on a 12 hour lightldark cycle.

\section{Experimental diet:}

The basal diet consists of casein $14 \%$, corn seed oil $10 \%$, salt mixture $3.5 \%$, vitamin mixture $1 \%$, corn starch $56.7 \%$, sucrose $10 \%$, fiber $5 \%$ and choline choride 0.25 according to (Reeves et al., 1993).

\section{Chemical analyses:}

Dried powdered carob, ginger root were analyzed chemically for carbohydrate, total protein, fat, moisture, crude fiber, and ash (g) according to AOAC, (1990).

\section{Experimental Design:}

Rats were divided into eight groups; each group included 7 rats caged individually. Food and water were provided adlibitum; all rats were individually in cylindrical wire cages weighed before and at the end of the experiment after six weeks. The first group, 7 normal rats, was fed on standard diet (negative control). The other 49 rats were injected intraperitoneally with a single dose of cis-diammine dichloride platinium ( $2.5 \mathrm{mg} / \mathrm{kg}$ body weight) after first week then divided into groups according to the following, the second group was fed on standard diet (positive control), the third group was fed on standard diet including $0.5 \%$ powder carob, the fourth group was fed on standard diet including $1 \%$ powder carob, while the fifths group was fed on standard diet including $5 \%$ powder carob the sixth group fed on standard diet including $0.5 \%$ powder ginger, the seventh group was fed on standard diet including $1 \%$ powder ginger, while the eighth group was fed on standard diet including $5 \%$ powder ginger. Carob, ginger was added instead of corn starch.

\section{Induction of renal dysfunction:}

Cis-diammine dichloride platinum (CDDP) for inducing renal dysfunction was used. 49 rats were injected intraperitoneally with a single dose of cis-diammine dichloride platinium ( $2.5 \mathrm{mg} / \mathrm{kg}$ body weight) was dissolved in physiological saline solution ( $1 \mathrm{mg} / \mathrm{ml}$ ) within one hour before injection according to (Iseri et al., 2007).

\section{Collection of blood samples:}

After the fasting overnight rats were sacrificed under the anesthesia. Blood samples were withdrawn from the hepatic portal vein in heparinized tubes. Blood was centrifuged at 3500 r.p.m. for 15 min., plasma samples were carefully separated and stored frozen at $-20^{\circ} \mathrm{C}$ for different biochemical analysis.

\section{Biological studies:}

Body weight gain:

All rats were individually weighed at the beginning, twice weekly in the first four weeks and then once weekly in following two weeks. The total diet consumed per group during the period of experiment was calculated by subtracting the diet remaining for each rat at the end of the interval of weighing from that allocated to the rats at the start of the intervals. Feed wastage was subtracted from that allocated to the rats.

\section{Biochemical analysis:}

Serum was used to determine total lipid (Knight et al., 1972), total cholesterol (Richmond, 1973), triglyceride (Koditscheck and Umbreit, 1969), high density lipoprotein (Fruchart, 1982), low density lipoprotein (Friedwold et al., 1972), and very low density lipoprotein cholesterol (Friedwold et al., 1972), Uric acid (Fossati et al., 1980), Urea Nitrogen (Patton and Crouch, 1977), Nitric oxide (Montgomery and Dymock, 1961), Albumin (Doumas et al., 1971), and Creatinine (Bartels and Bohmer, 1971). 
Statistical analysis

The obtained results of biological evaluations were statistically analyzed according to statistical analysis system. SAS User's Guide, (SAS, 2004). LSD at $5 \%$ level of significance was used to compare between means according to Snedecor and Cochran, (1980).

\section{Results and Discussion}

The results in Table (1) indicated that the body weight gain for normal rats (control A) was $68 \mathrm{~g}$, while it was decreased for the cisplatin-treated rats (control B) to be $44 \mathrm{~g}$, the reduction in body weight gain were $35 \%$. The same trend was observed with feed intake and feed efficiency ratio. In contrast, kidney and liver weight for the cisplatin-treated rats were increased by 51.5 and $20.2 \%$ respectively, compared with the normal rats. These results were agreement with Saad et al., (2009), who reported that administration of cisplatin to rats caused a significant reduction in final body weight in addition to a significant increase in kidney weight compared to the control group.

Table (1):

Change in body weight, liver and kidney weights, feed intake and feed efficiency ratio (FER) of the control and experimental rats.

\begin{tabular}{|c|c|c|c|c|c|c|c|c|}
\hline Diets & $\begin{array}{l}\text { Initial body } \\
\text { weight (g) }\end{array}$ & $\begin{array}{l}\text { Final body } \\
\text { weight }(g)\end{array}$ & $\begin{array}{l}\text { Bodyweight } \\
\text { gain (g) }\end{array}$ & $\begin{array}{l}\text { Liver } \\
\text { weight }(\mathrm{g})\end{array}$ & $\begin{array}{l}\text { Kidney } \\
\text { weight (g) }\end{array}$ & $\begin{array}{l}\text { Feed } \\
\text { intake }(\mathrm{g})\end{array}$ & $\begin{array}{l}\text { Daily feed } \\
\text { intake (g) }\end{array}$ & FER \% \\
\hline Control A & $193 \pm 3.32$ & $261 \pm 9.71$ & $68 \pm 11.13$ & $3.36 \pm 0.47$ & $0.97 \pm 0.07$ & $703 \pm 36.84$ & $17 \pm 0.88$ & $9.7 \pm 1.92$ \\
\hline Control B & $192 \pm 4.75$ & $236 \pm 4.04$ & $44 \pm 4.45$ & $4.04 \pm 0.36$ & $1.47 \pm 0.21$ & $587 \pm 51.82$ & $14 \pm 1.23$ & $7.58 \pm 1.1$ \\
\hline Group 1 & $191 \pm 3.82$ & $242 \pm 5.05$ & $51 \pm 6.09$ & $3.9 \pm 0.66$ & $1.21 \pm 0.25$ & $563 \pm 20.78$ & $13 \pm 0.49$ & $9.09 \pm 1.18$ \\
\hline Group 2 & $191 \pm 4.03$ & $244 \pm 4.24$ & $53 \pm 6.52$ & $3.96 \pm 0.37$ & $1.07 \pm 0.25$ & $602 \pm 60.36$ & $14 \pm 1.44$ & $8.86 \pm 1.36$ \\
\hline Group 3 & $193 \pm 3.9$ & $252 \pm 7.48$ & $59 \pm 9.51$ & $4 \pm 0.22$ & $0.93 \pm 0.05$ & $676 \pm 46.45$ & $16 \pm 1.11$ & $8.76 \pm 1.41$ \\
\hline Group 4 & $190 \pm 6.42$ & $241 \pm 5.86$ & $51 \pm 6.34$ & $3.86 \pm 0.48$ & $1.33 \pm 0.33$ & $587 \pm 41.75$ & $14 \pm 0.99$ & $8.72 \pm 0.99$ \\
\hline Group 5 & $191 \pm 5.68$ & $242 \pm 7.3$ & $51 \pm 5.18$ & $3.9 \pm 0.48$ & $1.19 \pm 0.27$ & $574 \pm 35.04$ & $14 \pm 0.83$ & $8.97 \pm 1.3$ \\
\hline Group 6 & $191 \pm 3.98$ & $251 \pm 7.72$ & $60 \pm 9.2$ & $3.99 \pm 0.65$ & $0.94 \pm 0.08$ & $680 \pm 49.6$ & $16 \pm 1.18$ & $8.99 \pm 1.91$ \\
\hline
\end{tabular}

Control A: Normal rats fed on a basal diet

Control B: Experimental rats fed on basal diet

Group 1: Experimental rats fed on basal diet $+0.5 \%$ dried powdered carob

Group 2: Experimental rats fed on basal diet $+1 \%$ dried powdered carob

Group 3: Experimental rats fed on basal diet $+5 \%$ dried powdered carob

Group 4: Experimental rats fed on basal diet $+0.5 \%$ ginger root

Group 5: Experimental rats fed on basal diet $+1 \%$ ginger root

Group 6: Experimental rats fed on basal diet $+5 \%$ ginger root

Cisplatin-induced weight loss, already reported by other authors, may be due to gastrointestinal toxicity or by lessened ingestion of food (Appenroth et al., 1997). Cisplatin-treated rats fed on basal diet supplemented with carob or ginger at different concentrations was significantly increased in body weight gain and decrease in kidney and liver weight compared to rats receiving cisplatin alone. Ramudu et al., (2011) reported that the decreased body weight in diabetic 


\section{Egypt. J. of Nutrition and Health Vol. 7 No. 1 (2012)}

rats were significantly regained on receiving ginger extract treatment than that of diabetic untreated rats. Ginger treatment of the diabetic rats produced increased body weight compared to untreated diabetic rats. This could be due to lowering of glucose levels, poly urea and ginger can also prevent osmotic degradation. These results were in agreement with the present study. The same trend was observed in feed intake and feed efficiency ratio for all animal.

Table (2):

Albumin, creatinine, urea, uric acid, and nitric oxide of the control and experimental rats.

\begin{tabular}{l|l|l|l|l|l}
\hline Diets & Albumin $(\mathrm{mg} / \mathrm{dl})$ & $\begin{array}{l}\text { Creatinine } \\
(\mathrm{mg} / \mathrm{dl})\end{array}$ & Urea $(\mathrm{mg} / \mathrm{dl})$ & $\begin{array}{l}\text { Uric } \\
(\mathrm{mg} / \mathrm{dl})\end{array}$ & $\begin{array}{l}\text { Nitric } \\
(\mathrm{mg} / \mathrm{dl})\end{array}$ \\
\hline Control A & $3.13 \pm 0.48$ & $0.53 \pm 0.08$ & $19.99 \pm 1.64$ & $1.56 \pm 0.17$ & $12.57 \pm 0.59$ \\
Control B & $2.37 \pm 0.40$ & $1.94 \pm 0.25$ & $29.07 \pm 1.16$ & $2.53 \pm 0.48$ & $26.50 \pm 1.83$ \\
Group 1 & $2.83 \pm 0.58$ & $1.33 \pm 0.22$ & $26.67 \pm 0.51$ & $1.97 \pm 0.41$ & $19.26 \pm 1.00$ \\
Group 2 & $2.99 \pm 0.32$ & $1.07 \pm 0.09$ & $25.36 \pm 0.42$ & $1.76 \pm 0.33$ & $18.90 \pm 0.84$ \\
Group 3 & $3.09 \pm 0.27$ & $0.84 \pm 0.09$ & $21.21 \pm 0.30$ & $1.68 \pm 0.16$ & $13.81 \pm 1.43$ \\
Group 4 & $2.87 \pm 0.46$ & $1.31 \pm 0.11$ & $25.19 \pm 0.36$ & $1.94 \pm 0.14$ & $19.74 \pm 3.32$ \\
Group 5 & $2.94 \pm 0.47$ & $1.16 \pm 0.17$ & $24.33 \pm 0.46$ & $1.81 \pm 0.28$ & $18.06 \pm 2.03$ \\
Group 6 & $3.10 \pm 0.35$ & $0.84 \pm 0.10$ & $21.03 \pm 0.81$ & $1.69 \pm 0.12$ & $13.56 \pm 2.03$ \\
\hline
\end{tabular}

Control A: Normal rats fed on a basal diet

Control B: Experimental rats fed on basal diet

Group 1: Experimental rats fed on basal diet $+0.5 \%$ dried powdered carob

Group 2: Experimental rats fed on basal diet $+1 \%$ dried powdered carob

Group 3: Experimental rats fed on basal diet $+5 \%$ dried powdered carob

Group 4: Experimental rats fed on basal diet $+0.5 \%$ ginger root

Group 5: Experimental rats fed on basal diet $+1 \%$ ginger root

Group 6: Experimental rats fed on basal diet $+5 \%$ ginger root

Cisplatin administration caused abnormal renal functions in cisplatin-treated rats (control B). Serum urea and creatinine concentrations were significantly increased $(P<0.5)$ in the cisplatin treated rats compared to the normal rats (control A) (Table 2). The concentrations of serum creatinine and urea in the carob or ginger (5\%) treated group were reduced to $56.7 \%$ and $27.0 \%$, respectively, with respect to the control B group.

Cisplatin has been shown to cause nephrotoxicity in patients (Daugaard et al., 1988; DeConti et al., 1973) as well as in a variety of animal species (Badary et al., 1997a; Badary et al., 1997b; McKeage et al., 1993). Administration of cisplatin exerts significant increase in serum urea and creatinine concentrations compared to normal group, which clearly indicates acute renal failure. The effect of cisplatin was similar to those previously described (Heidemann et al., 1989; McKeage et al., 1993; Somani et al., 2000). Carob and ginger ameliorated cisplatin-induced nephrotoxicity as indicated by significant less increase in serum urea and creatinine concentrations. The same trend was observed with uric acid and nitric oxide. Our results agreed with Ahmed's study (2010) which denoted that Carob polyphenols had a nephroprotective effect against cisplatin.

Also, these findings were in agreement with Mehrdad et al., (2007) who stated that ginger has a beneficial effect for removal of urea and creatinine from plasma of normal mice treated with its alcoholic extract and considered as a therapeutic herb to manage renal function. 
Table (3):

Total cholesterol (TC), very low (vLDL), low (LDL), high density lipoprotein (HDL), tri glycerides and total lipids (TL) of the control and experimental rats.

\begin{tabular}{l|l|l|l|l|l|l}
\hline Diets & TC $(\mathrm{mg} / \mathrm{dl})$ & vLDL $(\mathrm{mg} / \mathrm{dl})$ & LDL $(\mathrm{mg} / \mathrm{dl})$ & HDL $(\mathrm{mg} / \mathrm{dl})$ & TG $(\mathrm{mg} / \mathrm{dl})$ & TL $(\mathrm{mg} / \mathrm{dl})$ \\
\hline Control A* & $89.69 \pm 5.09$ & $14.62 \pm 0.56$ & $22.10 \pm 4.99$ & $54.23 \pm 1.22$ & $73.53 \pm 2.51$ & $310.41 \pm 2.50$ \\
Control B* & $138.79 \pm 2.95$ & $28.99 \pm 0.85$ & $59.67 \pm 3.72$ & $50.67 \pm 1.12$ & $145.07 \pm 4.11$ & $443.79 \pm 3.22$ \\
Group 1 & $126.59 \pm 3.97$ & $24.90 \pm 0.78$ & $51.00 \pm 2.33$ & $51.44 \pm 1.00$ & $122.01 \pm 5.13$ & $398.80 \pm 31.97$ \\
Group 2 & $116.44 \pm 2.51$ & $23.23 \pm 0.52$ & $46.97 \pm 4.42$ & $50.96 \pm 1.01$ & $115.7 .0 \pm 3.00$ & $363.53 \pm 34.36$ \\
Group 3 & $91.49 \pm 4.8$ & $17.59 \pm 1.13$ & $20.57 \pm 4.04$ & $53.67 \pm 0.94$ & $86.99 \pm 3.95$ & $313.00 \pm 3.51$ \\
Group 4 & $117.16 \pm 2.4$ & $24.06 \pm 1.07$ & $46.10 \pm 4.98$ & $49.61 \pm 0.97$ & $121.07 \pm 2.51$ & $397.19 \pm 4.31$ \\
Group 5 & $110.50 \pm 5.68$ & $17.61 \pm 0.61$ & $39.33 \pm 1.92$ & $51.36 \pm 1.52$ & $89.94 \pm 4.53$ & $379.94 \pm 12.45$ \\
Group 6 & $92.07 \pm 2.77$ & $15.89 \pm 0.38$ & $20.70 \pm 2.94$ & $54.49 \pm 1.53$ & $79.14 \pm 2.59$ & $316.73 \pm 3.58$ \\
\hline
\end{tabular}

Control A: Normal rats fed on a basal diet

Control B: Experimental rats fed on basal diet

Group 1: Experimental rats fed on basal diet $+0.5 \%$ dried powdered carob

Group 2: Experimental rats fed on basal diet $+1 \%$ dried powdered carob

Group 3: Experimental rats fed on basal diet $+5 \%$ dried powdered carob

Group 4: Experimental rats fed on basal diet $+0.5 \%$ ginger root

Group 5: Experimental rats fed on basal diet $+1 \%$ ginger root

Group 6: Experimental rats fed on basal diet $+5 \%$ ginger root

Hyperlipidaemia has been reported as a consistent feature of the nephrotic syndrome (Bagdade et al., 1968). The dyslipidaemia is normally associated with elevated levels of plasma cholesterol, triglyceride (TG), very low density lipoprotein (VLDL), high density lipoprotein cholesterol (HDL) and low density lipoprotein (LDL)-cholesterol (Appel, 1991). The high density lipoprotein (HDL) cholesterol may either be depressed, unchanged or increased (Olbricht and Koch, 1992). Hyperlipidaemia was also demonstrated in experimentally drug-induced nephrotic animals (Hirano et al., 1990).

According to the results in table (2), the serum cholesterol for normal rats (control A) was $89.69 \pm 5.09 \mathrm{mg} / \mathrm{dl}$, while it was increased for the cisplatin-treated rats (control B) to be $138.79 \pm 2.95 \mathrm{mg} / \mathrm{dl}$, the increase in serum cholesterol was $54.7 \%$. The LDL-cholesterol was also significantly $(P \leq 0.05$ ) rose (from $22.10 \pm 4.99$ to $59.67 \pm 3.72 \mathrm{mg} / \mathrm{d}$ ), the VLDLcholesterol in the animals was increased to more than twofold (from $14.62 \pm 0.56$ to $28.99 \pm 0.85 \mathrm{mg} / \mathrm{dl}$ ), for normal rats (control A) and cisplatin-treated rats (control B) respectively. Similarly, the serum triglyceride and total lipids concentration was significantly $(P \leq 0.05)$ increased by about $97 \%$ and $43 \%$ for cisplatin-treated rats (control B). On the other hand, the HDL-cholesterol was significantly decreased ( $P \leq 0.05$ ) (from $54.23 \pm 1.22$ to $50.67 \pm 1.12 \mathrm{mg} / \mathrm{dl}$ ), for normal rats (control A) and cisplatin-treated rats (control B) respectively. These results were in accordance to Abdel-Gayoum et al., (1999) who reported that the peak of nephrosis on day 5 was accompanied by severe hypercholesterolaemia and hypertriglyceridaemia. This was in congruence with the changes in plasma lipids observed in several drug-induced nephrotic animals (Hirano et al., 1990). Similar alterations in plasma cholesterol and TG levels were also determined in rats with nephrotic syndrome induced by passive Heyman nephrites (Sestak et al., 1989). 
The effects of carob and ginger on serum cholesterol, total glycerides and total lipid levels were determined by comparison of normal (control A), cisplatin-treated rats (control B), and cisplatin-treated rats fed on different concentration of carob or ginger. The rats given diet supplemented with carob at $(5 \%)$ showed a significant reduction in the serum total cholesterol and total triglycerides levels by $34.1 \%$ and $40.0 \%$, respectively. While rats given diet supplemented with ginger at $5 \%$ exhibited reduction in serum cholesterol and total triglycerides levels by 33.6 and $45.4 \%$, respectively (Table 3). The same trend was observed with vLDL, LDL, TL for carob or ginger at different concentration. In contrast the addition of carob or ginger led to increase of HDL levels at different concentration. The pod of the carob fruit (Ceratonia siliqua L.) contains $40-50 w t \%$ of sweet carbohydrates as well as dietary fiber and polyphenols (Marakis, 1996). Only the insoluble fiber of pulp of carob pod has shown hypocholesterolemic properties in animal (Ruiz-Roso et al., 2010) and human trials (Zunft et al., 2003).

The mechanism of reduction of serum lipid profile by dietary fiber is possibly a sum of several effects: an increase in the synthesis and excretion of bile acids, a reduction in the absorption of triglycerides, an inhibition of the endogenous synthesis of cholesterol by short-chain fatty acids generated in the large intestine and modifications in the metabolism of lipoproteins through an increase in the amount of hepatic receptors of LDLs (Brown et al., 1999; Fukushima et al., 2000; Gelissen et al., 1994).

However, it is commonly accepted that the majority of effects are due to decreased absorption of bile acids. This causes a removal of steroids from the body by fecal excretion resulting in elevated catabolism of cholesterol, a rise in the secretion of bile acids, a decrease in lipoprotein cholesterol secretion, and a reduction in the total body pool of cholesterol (Jenkins et al., 2001).

Moreover, the hypocholesterolaemic effects of ginger may be due to inhibition of cellular cholesterol synthesis (Ness et al., 1996). This may be due to the presence of niacin in ginger as reported in many studies that niacin causes increased clearance of VLDL, lowers triglyceride levels, increased hepatic uptake of LDL and inhibition of cholesterogenesis (Cardia et al., 1990; Durrington, 2003; Mary and John, 2000). The observed antihyperlipidemia effect of ginger may also be explained by the presence of high fiber and antinutrients such as phytic acid (Sharma, 1980).

\section{Conclusion}

Administration of cisplatin exerts significant increase in serum urea and creatinine concentrations compared to normal group, which clearly indicates the acute renal failure. Cisplatin-treated rats fed on basal diet supplemented with carob or ginger at different concentrations showed significant increase in body weight gain and decrease in kidney and liver weight compared to rats receiving cisplatin alone. Diet supplemented with carob or ginger showed a significant reduction in the serum total cholesterol and triglycerides levels. Carob and ginger ameliorated cisplatin-induced nephrotoxicity as indicated by significant decrease in serum urea and creatinine concentrations compared to the positive control. The same trend was observed with uric acid and nitric oxide. Thus, carob and ginger may be used to help in delaying the toxic effect during chemotherapeutic treatment with cisplatin. 


\section{References}

Abdel-Gayoum, A. A., El-Jenjan, K. B., and Ghwarsha, K. A. (1999).

Hyperlipidaemia in cisplatin-induced nephrotic rats. Hum Exp Toxicol 18, 454-9.

Ahmed, M. M. (2010).

Biochemical Studies on Nephroprotective Effect of Carob (Ceratonia siliqua L.) Growing in Egypt. Nature and Science 8, 41-47.

Ajith, T. A., Jose, N., and Janardhanan, K. K. (2002).

Amelioration of cisplatin induced nephrotoxicity in mice by ethyl acetate extract of a polypore fungus, Phellinus rimosus. J Exp Clin Cancer Res 21, 213-7.

AOAC (1990).

Association of Official Analytical Chemists. In "Official Methods of Analysis, 15th edition", Washington.

Appel, G. (1991).

Lipid abnormalities in renal disease. Kidney International 39, 169-173.

Appenroth, D., Fröb, S., Kersten, L., Splinter, F. K., and Winnefeld, K. (1997).

Protective effects of vitamin $E$ and $C$ on cisplatin nephrotoxicity in developing rats. Archives of Toxicology 71 , $677-683$.

Badary, O. A., Nagi, M. N., Al-Sawaf, H. A., Al-Harbi, M., and Al-Bekairi, A. M. (1997a).

Effect of L-histidinol on cisplatin nephrotoxicity in the rat. Nephron 77, 435-9.

Badary, O. A., Nagi, M. N., al-Shabanah, O. A., al-Sawaf, H. A., al-Sohaibani, M. O., and al-Bekairi, A. M. (1997b). Thymoquinone ameliorates the nephrotoxicity induced by cisplatin in rodents and potentiates its antitumor activity. Can J Physiol Pharmacol 75, 1356-61.

Bagdade, J. D., Porte, D., Jr., and Bierman, E. L. (1968).

Hypertriglyceridemia. A metabolic consequence of chronic renal failure. N Engl J Med 279, 181-5.

Bartels, H., and Bohmer, M. (1971).

[Micro-determination of creatinine]. Clin Chim Acta 32, 81-5.

Bompart, G. (1989).

Cisplatin-induced changes in cytochrome P-450, lipid peroxidation and drug-metabolizing enzyme activities in rat kidney cortex. Toxicol Lett 48, 193-9.

Bone, M. E., Wilkinson, D. J., Young, J. R., McNeil, J., and Charlton, S. (1990).

Ginger root--a new antiemetic. The effect of ginger root on postoperative nausea and vomiting after major gynaecological surgery. Anaesthesia 45, 669-71.

Brown, L., Rosner, B., Willett, W. W., and Sacks, F. M. (1999).

Cholesterol-lowering effects of dietary fiber: a meta-analysis. The American Journal of Clinical Nutrition 69, 3042. 


\section{Egypt. J. of Nutrition and Health Vol. 7 No. 1 (2012)}

Cardia, G., Grisorio, D., Impedovo, G., Lillo, A., and Regina, G. (1990).

Plasma lipids as a risk factor in peripheral vascular disease. Angiology 41, 19-22.

Daugaard, G., Abildgaard, U., Holstein-Rathlou, N. H., Bruunshuus, I., Bucher, D., and Leyssac, P. P. (1988). Renal tubular function in patients treated with high-dose cisplatin. Clin Pharmacol Ther 44, 164-72.

DeConti, R. C., Toftness, B. R., Lange, R. C., and Creasey, W. A. (1973).

Clinical and Pharmacological Studies with cis-Diamminedichloroplatinum(II). Cancer Research 33, 1310-1315.

Doumas, B. T., Watson, W. A., and Biggs, H. G. (1971).

Albumin standards and the measurement of serum albumin with bromcresol green. Clin Chim Acta 31, 87-96.

Durrington, P. (2003).

Dyslipidaemia. The Lancet 362, 717-731.

Fossati, P., Prencipe, L., and Berti, G. (1980).

Use of 3,5-dichloro-2-hydroxybenzenesulfonic acid/4-aminophenazone chromogenic system in direct enzymic assay of uric acid in serum and urine. Clin Chem 26, 227-31.

Friedwold, W. T., Levy, R. I., and Fredrickson, D. S. (1972).

Estimation of the concentration of low-density lipoprotein cholesterol in plasma without use of the preparative ultracentrifuge. Clin. Chem 18, 499-502.

Fruchart, J. C. (1982).

Rev. Fn. Des Laboratories 103, 7-10.

Fukushima, M., Nakano, M., Morii, Y., Ohashi, T., Fujiwara, Y., and Sonoyama, K. (2000).

Hepatic LDL receptor mRNA in rats is increased by dietary mushroom (Agaricus bisporus) fiber and sugar beet fiber. J Nutr 130, 2151-6.

Gelissen, I., Brodie, B., and Eastwood, M. (1994).

Effect of Plantago ovata (psyllium) husk and seeds on sterol metabolism: studies in normal and ileostomy subjects. The American Journal of Clinical Nutrition 59, 395-400.

Goldstein, R. S., and Mayor, G. H. (1983).

Minireview. The nephrotoxicity of cisplatin. Life Sci 32, 685-90.

Grontved, A., Brask, T., Kambskard, J., and Hentzer, E. (1988).

Ginger root against seasickness. A controlled trial on the open sea. Acta Otolaryngol 105, 45-9.

Gruenwald, J., Brendler, T., and Jaenicke, C. (2000). "PDR for herbal medicines," 2nd/Ed. Medical Economics Company, Inc, Montvale, NJ.

Haber, B. (2002).

Carob fiber benefits and application. Cereal Foods World 47, 365-369.

Halliwell, B., and Cross, C. E. (1994).

Oxygen-derived species: their relation to human disease and environmental stress. Environ Health Perspect 102 Suppl 10, 5-12. 


\section{Ereny Wilson and Haiam Elkatry}

Heidemann, H. T., Muller, S., Mertins, L., Stepan, G., Hoffmann, K., and Ohnhaus, E. E. (1989).

Effect of aminophylline on cisplatin nephrotoxicity in the rat. British journal of pharmacology 97, 313-8.

Hirano, T., Mamo, J. C., Ohnami, K., and Sugisaki, T. (1990).

Treatment of hyperlipidemia with probucol reduces proteinuria in puromycin aminonucleoside-induced nephrotic rats. Nephron 54, 358-9.

Iseri, S., Ercan, F., Gedik, N., Yuksel, M., and Alican, I. (2007).

Simvastatin attenuates cisplatin-induced kidney and liver damage in rats. Toxicology 230, 256-64.

Jenkins, A., Vuksan, V., and Jenkins, D. (2001).

Fiber in the treatment of hyperlipidemia. In "Handbook of dietary fiber in human nutrition" (S. GA, ed.), pp. $401-$ 421. CRC Press LLC, Boca Raton.

Kivçak, B., Mert, T., and Ozturk, H. T. (2002).

Antimicrobial and cytotoxic activity of Ceratonia siliqua L. Extracts. Turk Journal Biology 26, 197-200.

Knight, J. A., Anderson, S., and Rawle, J. M. (1972).

Chemical basis of the sulfo-phospho-vanillin reaction for estimating total serum lipids. Clin Chem 18, 199-202.

Koditscheck, L. K., and Umbreit, W. W. (1969).

Determination of triglyceride in blood. J. Bacteriol 98, 1063- 1068.

Kumazawa, S., Taniguchi, M., Suzuki, Y., Shimura, M., Kwon, M. S., and Nakayama, T. (2002).

Antioxidant activity of polyphenols in carob pods. J Agric Food Chem 50, 373-7.

Lieberthal, W., Triaca, V., and Levine, J. (1996).

Mechanisms of death induced by cisplatin in proximal tubular epithelial cells: apoptosis vs. necrosis. Am J Physiol 270, F700-8.

Marakis, S. (1996).

Carob bean in food and feed: Current status and future potentials - a critical appraisal. J. Food Sci. TechnoL 33, 365-383.

Mary, J., and John, P. (2000).

Agents used in hyperlipidaemia. In "Basic and clinical pharmacology" (K. BG, ed.), pp. 581-595. McGraw Hill Comp, New York.

Matsushima, H., Yonemura, K., Ohishi, K., and Hishida, A. (1998).

The role of oxygen free radicals in cisplatin-induced acute renal failure in rats. $J$ Lab Clin Med 131, 518-26.

McKeage, M. J., Morgan, S. E., Boxall, F. E., Murrer, B. A., Hard, G. C., and Harrap, K. R. (1993).

Lack of nephrotoxicity of oral ammine/amine platinum (IV) dicarboxylate complexes in rodents. Br J Cancer 67 , 996-1000.

Mehrdad, M., Messripour, M., and Ghobadipour, M. (2007).

The effect of ginger extract on blood urea nitrogen and creatinine in mice. Pak J Biol Sci 10, 2968-71. 
Montgomery, H. A. C., and Dymock, J. F. (1961).

Colorimetric determination of nitric oxide. Analyst 86, 414-417.

Murcia, M. A., Egea, I., Romojaro, F., Parras, P., Jimenez, A. M., and Martinez-Tome, M. (2004).

Antioxidant evaluation in dessert spices compared with common food additives. Influence of irradiation procedure. J Agric Food Chem 52, 1872-81.

Ness, G. C., Zhao, Z., and Lopez, D. (1996).

Inhibitors of cholesterol biosynthesis increase hepatic low-density lipoprotein receptor protein degradation. Arch Biochem Biophys 325, 242-8.

Ney, D. M., Lasekan, J. B., and Shinnick, F. L. (1988).

Soluble oat fiber tends to normalize lipoprotein composition in cholesterol-fed rats. J Nutr 118, 1455-62.

Olbricht, C. J., and Koch, K. M. (1992).

Treatment of hyperlipidemia in nephrotic syndrome: time for a change? Nephron 62, 125-9.

Owen, R. W., Haubner, R., Mier, W., Giacosa, A., Hull, W. E., Spiegelhalder, B., and Bartsch, H. (2003). Isolation, structure elucidation and antioxidant potential of the major phenolic and flavonoid compounds in brined olive drupes. Food Chem Toxicol 41, 703-17.

Papagiannopoulos, M., Wollseifen, H. R., Mellenthin, A., Haber, B., and Galensa, R. (2004).

Identification and quantification of polyphenols in carob fruits (Ceratonia siliqua L.) and derived products by HPLC-UV-ESI/MSn. J Agric Food Chem 52, 3784-91.

Patton, C. J., and Crouch, S. R. (1977).

Spectrophotometric and kinetics investigation of the Berthelot reaction for the determination of ammonia. . Anal. Chem. 49, 464-469.

Ramudu, S. K., Korivi, M., Kesireddy, N., Lee, L. C., Cheng, I. S., Kuo, C. H., and Kesireddy, S. R. (2011). Nephro-protective effects of a ginger extract on cytosolic and mitochondrial enzymes against streptozotocin (STZ)-induced diabetic complications in rats. Chin J Physiol 54, 79-86.

Reeves, P. G., Nielsen, F. H., and Fahey, G. C., Jr. (1993).

AIN-93 purified diets for laboratory rodents: final report of the American Institute of Nutrition ad hoc writing committee on the reformulation of the AIN-76A rodent diet. J Nutr 123, 1939-51.

Richmond, W. (1973).

Preparation and properties of a cholesterol oxidase from Nocardia sp. and its application to the enzymatic assay of total cholesterol in serum. Clin Chem 19, 1350-6.

Ruiz-Roso, B., Quintela, J., de la Fuente, E., Haya, J., and Pérez-Olleros, L. (2010).

Insoluble Carob Fiber Rich in Polyphenols Lowers Total and LDL Cholesterol in Hypercholesterolemic Sujects. Plant Foods for Human Nutrition (Formerly Qualitas Plantarum) 65, 50-56.

Saad, A. A., Youssef, M. I., and El-Shennawy, L. K. (2009).

Cisplatin induced damage in kidney genomic DNA and nephrotoxicity in male rats: the protective effect of grape seed proanthocyanidin extract. Food Chem Toxicol 47, 1499-506. 
SAS (2004).

SAS Online Doc_9.1. SAS Institute Inc., Cary, NC.

Sestak, T. L., Alavi, N., and Subbaiah, P. V. (1989).

Plasma lipids and acyltransferase activities in experimental nephrotic syndrome. Kidney Int 36, 240-8.

Sharma, R. D. (1980).

Effect of hydroxy acids on hypercholesterolaemia in rats. Atherosclerosis 37, 463-8.

Simic, M. G., and Jovanovic, S. V. (1986).

Free radical mechanisms of DNA base damage. Basic Life Sci 38, 39-49.

Snedecor, G. W., and Cochran, W. G. (1980).

"Statistical Methods," 7th Edn/Ed. lowa State University Press, lowa, USA.

Somani, S. M., Husain, K., Whitworth, C., Trammell, G. L., Malafa, M., and Rybak, L. P. (2000).

Dose-dependent protection by lipoic acid against cisplatin-induced nephrotoxicity in rats: antioxidant defense system. Pharmacol Toxicol 86, 234-41.

Sripramote, M., and Lekhyananda, N. (2003).

A randomized comparison of ginger and vitamin B6 in the treatment of nausea and vomiting of pregnancy. $J$ Med Assoc Thai 86, 846-53.

Sweetman, S. C. (2002).

Antineoplastic and immunosupressants. In "Martindale: The Complete Drug Reference" (S. C. Sweetman, ed.), pp. 525-527. Pharmaceutical Press, London, UK.

Thomson, M., Al-Qattan, K. K., Al-Sawan, S. M., Alnaqeeb, M. A., Khan, I., and Ali, M. (2002).

The use of ginger (Zingiber officinale Rosc.) as a potential anti-inflammatory and antithrombotic agent. Prostaglandins Leukot Essent Fatty Acids 67, 475-8.

Zunft, H. J., Luder, W., Harde, A., Haber, B., Graubaum, H. J., and Gruenwald, J. (2001).

Carob pulp preparation for treatment of hypercholesterolemia. Adv Ther 18, 230-6.

Zunft, H. J., Luder, W., Harde, A., Haber, B., Graubaum, H. J., Koebnick, C., and Grunwald, J. (2003).

Carob pulp preparation rich in insoluble fibre lowers total and LDL cholesterol in hypercholesterolemic patients.

Eur J Nutr 42, 235-42. 
Egypt. J. of Nutrition and Health Vol. 7 No. 1 (2012)

تأثير عشب الخروب والزنجبيل علي سمية الكلي المستحث في الفئران

إيريني ولسن ، هيام القطري

قسم الاقتصاد المنزلي، كلية التربية النوعية، جامعة عين شمس

$$
\text { الملخص العربي }
$$

الخروب والزنجبيل هي نباتات تتواجد في منطقة البحر الأبيض المتوسط، وتستخدم أساسا في المواد الغذانية والطب الشعبي التقليدي

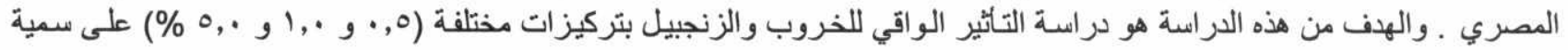

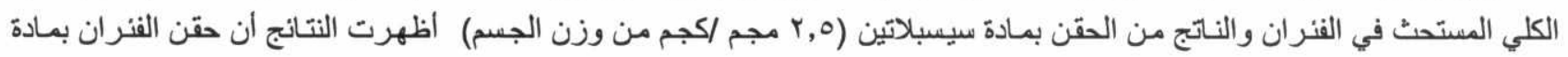

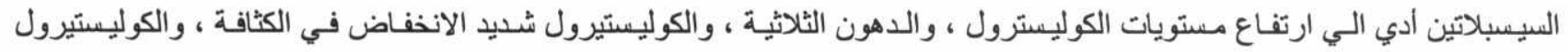

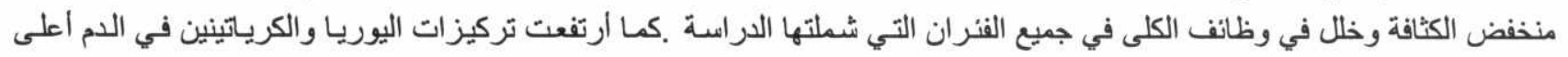

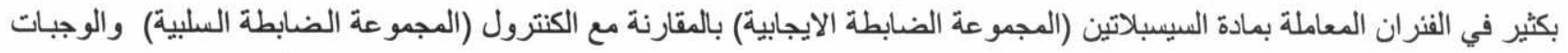

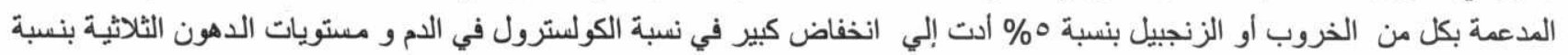

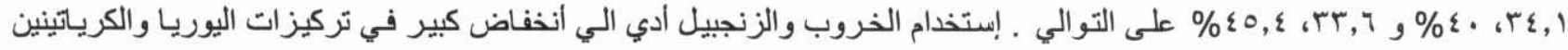

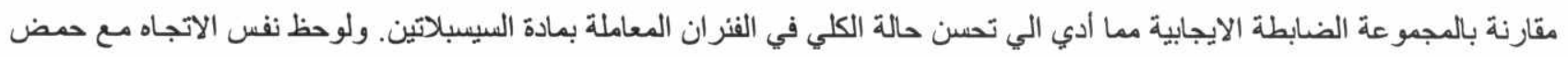
اليوريك واكسيد النتريك ـ وبالتالي، يمكن استخدام الخروب والزنجبيل لتقليل التأثير السام من العلاج الكيمياني بمادة السيسبلاتين. 